\section{POST-PANDEMIC CITY: HISTORICAL CONTEXT FOR NEW URBAN DESIGN}

\author{
Veaceslav MIR
}

\section{Veaceslav MIR}

$\mathrm{PhD}$ candidate, School of Public Administration and Public Policies, Faculty of Political, Administrative, and Communication Sciences,

Babeș-Bolyai University, Cluj-Napoca, Romania

Tel.: 0040-770-725.425

E-mail: veaceslavmir@gmail.com
DOI: $10.24193 /$ tras.SI2020.6

Published First Online: 11/23/2020 


\section{Introduction}

Cities have existed for about 10,000 years (Perlman, 1983, p. 16), and for about the same period cities have been plagued by various epidemics. Therefore, from a formal point of view, the city has changed relatively little. It still implies a large number of people living compactly in the common territory with developed infrastructure, where there is a constant exchange of goods, services and knowledge - generally speaking, those are the non-agricultural tasks (Caves, 2004, p. 99).

Throughout the history of cities, there have been urban theorists who have proposed various ways to improve the city as a threat-free habitat, consequently developing the concept of ideal city. The first ideal city concept was developed by Plato around $375 \mathrm{BCE}$. In the work 'The Republic' he proposed the theory of functional urban zoning (Plato, translated by Cornford, 1970, pp. 56-59). Attempts to translate ideal cities into reality were made during the Renaissance, based on ideas expressed in 'Utopia' by Thomas More (More, translated by Baker-Smith, 2012, pp. 5-146), 'City of the Sun' by Tommaso Campanella (Campanella, translated by Donno, 1981, pp. 23-128), and 'New Atlantis' by Francis Bacon (Bacon, translated by Vickers, 2008, pp. 457-490). The image of the ideal city of the Renaissance was captured on painting 'Città ideale' - 'long rectangular painting depicting an antique but beautiful perspective from the hand of Carnevale' (Hansen et al., 2005, pp. 62-67). This ideal city painting represented a metaphor of the good governance and well-organized society, which looks quite modern even nowadays. Epidemics notably contributed to the urban development as a movement for a better quality of life. In particular, the first catalyst for the urban development became the plague epidemic, which affected all spheres of life from economic to cultural, similar to the way in which the COVID-19 pandemic did.

\section{Pandemics and epidemics as a factor of urban development: historical context and nowadays parallels}

\subsection{The Black Death and the urban environment}

The beginning of the world history of pandemics was laid by the Black Death or Plague, which later even began to appear as one of the Horsemen of the Apocalypse. The first documented epidemic was the Antonine Plague in 165-180 CE (Sicker, 2000, p. 169), then followed by the Justinianic Plague pandemic in 541-549 CE (Mordechai et al., 2019, pp. 25546) and the Black Death pandemic in 1347-1351 (Ziegler, 1998, p. 40), which became the largest pandemic in history (Gottfried, 1983, p. 9).

It is interesting that the epidemiologic measures against COVID-19 are pretty similar with those against plague in Medieval Europe. Principally, quarantine and self-isolation became the main measures. The Quarantine Practice as a restriction on the movement of people appeared in the Italian city-state Republic of Ragusa, Dalmatia (modern Dubrovnik in Croatia) in 1377 (Mackowiak et al., 2002, p. 1071). There was introduced the trentino-law - a thirty-day isolation of newly arrived in 
the city. Later, other cities began to introduce the same epidemiologic norms, but in Venice trentino lengthened to 'quaranta' - a forty-day isolation of newly arrived.

Self-isolation as a preventive measure was also used as nowadays. But during the $14^{\text {th }}$ century self-isolating was affordable only for the richest people of the city, who hastily left for suburban villas. The most striking example of self-isolation is described in 'Decameron' by Giovanni Boccacio (Bocaccio, translated by McWilliam, 2003, pp. 4-797). All these led to a decrease in the density of contacts among the population, which favored the fight against the pandemic.

Absolutely all the segments of the population were exposed to the disease, including the highest nobility as queen Eleanor of Portugal (De Almeida Rodrigues, 2013, p. 93) or highest clerics as Archbishop of Canterbury Thomas Bradwardine (Cantor, 2001, pp. 110-125). It became clear that disease is a common problem, and that the walls of castles or churches do not protect against the malady. It was the moment for developing epidemiological measures for the urban environment. Various medical facilities appeared or were reconstructed, including Transylvanian cities such as Cluj-Napoca (Rusu, 2018, pp. 67-82) where the first xenodochium were built in 1061 CE (Ifrim, 2018, p. 219). From the socio-economic point of view, the plague pandemic led to an increase in wages due to the lack of the required number of workers, and the reform of the labor market. At the same time, this led to an increase of taxes and more stringent regulation of the market (Herlihy, 1997, p. 49).

A similar process can be observed in the case of current coronavirus SARS-CoV-2 pandemic: self-isolation, active implementation of a remote work format, as well as stricter regulation of certain market niches (medical products) by the state (PL-x nr. 133/2020).

\subsection{Modern city and epidemics}

The appearance of modern cities took shape only in the $19^{\text {th }}$ century, inclusively due to epidemics that forced local public administration to think about the functionality of urban planning. It was the epidemics that forced the city authorities to take care of urban improvements: to carry out water supply, to start building relatively affordable rental housing with sanitary norm abidance, on planned land plots to exclude the formation of slums, to arrange public spaces in cities: starting with parks to an organized network of streets and boulevards.

The main example of urban improvement can be called the haussmannisation of Paris - the reconstruction of the central part of the French capital under the leadership of Baron Georges-Eugène Haussmann (De Moncan, 2002, p. 10), between 1853 and 1870. By the beginning of the Second Empire the center of Paris was a variety of slums of the socially vulnerable groups with a high population density, an intricate network of narrow medieval roads, with a complete lack of hygienic infrastructure (De Moncan, 2002, p. 10). According to Haussmann's plan, the center of the capital was significantly changed: the old houses of the poor were demolished, wide and straight streets were laid through the city, new administrative buildings were built on 
the liberated territory (Kirkland, 2014, pp. 3-26), the island of Cité was almost completely redeveloped (Gagneux et al., 2004, p. 10), numerous parks were created. One of the most significant parts of the renovation, from epidemiological point of view, was the construction of the modern sewer system (Gandy, 1999, pp. 23-44).

From a social point of view, such innovations pursued several goals. The first goal: improving the living conditions of the poorest citizens (Milza, 2004, pp. 189-190). However, this led to the fact that these social categories were evicted to the outskirts of the city (Maneglier, 1990, p. 42), while wealthy bourgeoisie poured into the city center, thus triggering the process of gentrification of these once poor areas (Jordan, 2004, p. 99). The second goal: to prevent riots in the capital. Narrow medieval streets were perfect for creating barricades, allowing violent political or social protests (Maneglier, 1990, p. 19). The third goal: improving the hygiene conditions of the city. The main problems of the cities of that time were cholera and tuberculosis (Papayanis, 2004, p. 79). By the time the haussmannization of Paris began, Europe was already shocked by several cholera epidemics. The sewers networks laid by Eugene Belgrand in the underground tunnels made it possible to solve the problem of Seine pollution. This principle of laying communications is still used in contemporary cities (Goodman, 1999, pp. 113-116).

Almost at the same time as Paris, the current center of London was changing as well, one of the main reasons being an outbreak of cholera. During his successful investigation, Dr. John Snow identified the deadly water pump in Soho in 1854 by marking on the map all cases of infections and deaths, then he found out the exact place and cause of the disease (Brody, 2003, p. 30). To modernize the sewage system and to protect the city's water supply system, the banks of the Thames were re-arranged, in particular, the Victoria Embankment going from Westminster to the City of London. Before the reconstruction, private houses and industrial buildings stood on the shore close to the river so all sewage were discharged directly in the Thames (Dobraszczyk, 2014, pp. 8-9). Nowadays there are gardens, ceremonial state buildings, and the embankment itself has become the most important transport artery of the city.

Spanish flu in the early $20^{\text {th }}$ century was a powerful impetus for the development of housing construction of a new type (Mamelund, 2017, p. 6). Brand new standards were developed and implemented, each apartment had a reasonable amount of sunlight, space and fresh air, combining aesthetics with everyday function (Oxford Dictionary of Art and Artists, pp. 64-66). Huge public funds were invested to support the construction of mass public housing that could be bought or rented (Fact sheet on the Danish social housing sector, p. 8; Bauer, 2020; McCarty, 2014, pp. 2-8), as well as received from the state in the case of socialist camp countries (Meerovich, 2016, pp. 26-41).

COVID-19 pandemic is about to change the city in the same way: to redevelop its infrastructure and improve the living conditions, to improve the quality of life in the city. 


\section{Contemporary city in the context of pandemics: problems and solutions}

At the beginning of the $21^{\text {st }}$ century, issues of health care and health problems caused by environmental conditions, as well as the problems of mental health appeared on the agenda of contemporary megalopolises. According to estimates, depressive and anxiety disorders are much more common in the city (Bhugra et al., 2019, p. 32). To solve this problem, architects and designers primarily worked with the appearance of buildings and the urban environment. However, the agenda did not include prevention and crisis management in case of pandemics, although health experts warned quite a long time ago of the potential emergence of such pandemics (Cheng et al., 2007, p. 674).

\subsection{Developing flexible strategies}

The present situation revealed some important systemic problems - the lack of regulations for action in such situations, as well as a low level of trust between people and the government, including health workers as its representatives. At the same time, disbelief in the very existence of COVID-19, refusal of vaccination, socially irresponsible behavior violating quarantine, conspiracy theories (Spring, 2020) - all of these are not something new to deal with for a public administration. For example, during the plague epidemic in San Francisco at the beginning of the $20^{\text {th }}$ century, the situation developed in exactly the same way. The city was not ready for an epidemic, residents did not trust the authorities, violated quarantine, and wealthy businesses tried to influence the authorities so as not to incur losses (Kazanjian et al., 2012, p. 1377). That is why the main thing in a crisis situation in the city is to maintain confidence and to build trust between citizens and authorities, between the fighters against the epidemic and possible victims in order to effectively comply with pre-designed measures.

At the same time, strategies for managing a city during an epidemic or pandemic should be as flexible and adaptable as possible to the conditions and characteristics of the disease. This primarily concerns the health infrastructure. During peacetime, hos-

pitals are designed to create the most patient-friendly experience while maintaining budget and management efficiency. However, readiness of the medical institutions for a pandemic already at the project developing stage, with the same budget, means lowering the quality of everyday experience of patients and doctors, which can hardly be called a popular solution in the absence of a clear threat. It is much more appropriate to think about ready-made scenarios for reequipping spaces. Surprisingly, it is the sports and entertainment infrastructure that can host health care institutions in the shortest time during the crisis situations.

To avoid the crisis situation which took place in the United States after Hurricane Katrina at the Superdome Stadium (Cooper et al., 2006, p. 178), local public administration should prepare in advance some plans for repurposing public buildings. Along 
these lines, the Principality Stadium in the UK was transformed into a 2000 bed hospital (BBC, 27 March 2020), in Bergamo the pavilions of the Fiera di Bergamo exhibition center were reequipped (La Republica, 30 March, 2020), in Rotterdam the Ahoy concert venue where transformed into a hospital instead of hosting Eurovision 2020 (BBC, 17 April 2020).

\subsection{Decentralization of the city}

In the conditions of intense passenger traffic in contemporary cities, infections and viruses can spread with high speed. Decentralization of places of employment, both in space and in time, will significantly affect the patterns of mobility in cities, breaking the usual circular migration. The introduction of a remote work system will relieve the city centers: usually the offices are concentrated in the city center, which need to be reached from the commuter towns or suburban areas. In case of remote work such offices will lose their attractiveness. A new approach to the planning and development of business centers could be a functional solution: the development of a hub system of office spaces, similar to the organization of aviation hubs. This solution will enable people to work closer to their place of residence, avoiding crowded spaces in public transport (Elldér, 2017, p. 205). It will also bring the city's population closer to realizing the zero-kilometer approach (Losavio, 2011, p. 93) into the urban planning.

In this case, the workplace and the transport network will no longer be so closely interconnected. Traditional transport infrastructure planning schemes tied to roads capacity will lose their relevance. The need for individual transport may increase because of diverse remote working hours, and given the green vector of development declared by most cities, this will lead to a rethinking of the entire transport infrastructure. In New Zealand, city services began to widen sidewalks to give more space to pedestrians and cyclists (Reid, 2020), London's public administration plans to introduce a car-free regime on some streets (Cokelaere, 2020).

Such processes will also lead to an improvement in the environmental situation, and primarily to an improvement in air quality. In the context of the COVID-19 pandemic, this is especially important, since some studies have already found a correlation between the spread of coronavirus and air pollution in urban environments (Ogen, 2020, p. 2).

\section{Post-pandemic city: Urbanism v.3.0.}

One of the problems of the contemporary cities, which remains to be solved to prevent the accelerated spread of epidemics in the future, is the uneven distribution of residents throughout the city. There are densely populated areas - the prestigious ones, or vice versa - the slums, as well as sparsely populated areas, most often located on the outskirts of the city. The ideas of new urbanism, which emerged in the 1980s, aimed for even settlement in smaller communes centered around the city or even a network of such communities (Caves, 2004, p. 491). This is the main idea that should 
be taken into consideration for Urbanism v.3.0. development for a post-pandemic city development: small communes implement the theory of zero kilometer - work where you live, live where you work. This will reduce the congestion of the public transport network and roads, and also, in case of the construction of office hubs, will make all areas of the city relatively equally attractive for housing. In addition, in such areas the population density will be lower, which will lead to fewer physical contacts and will prevent the spread of the epidemic (Jayaweera et al., 2020, p. 14).

Indirectly, this is also confirmed by surveys of the poor and rich areas of large cities: the number of hospitalizations from poor areas has increased with the passage of quarantine, the reason is crowded living and fast infection of all family members from one random carrier (Baker et al., 2020, pp. 7-8). In this case, the communes developed in the spirit of Urbanism v.3.0. will be easier to isolate and deal with contamination within the community without blocking life throughout the city and concentrate resources for helping the damaged area. Communities of this type will also be easier to provide with everything they need in the context of the development of a contactless economy, which has proven its effectiveness in the pandemic time by significantly reducing the number of direct physical contacts between people. This applies not only to online shopping, but also to education and telemedicine, which will enable to provide a wide range of services to an isolated community.

As it was in the cities of the Antiquity or Renaissance, nowadays the epidemic is transforming the familiar lifestyle, erasing the boundaries of the permissible, while simultaneously launching large-scale reconstruction and adjusting the urban infrastructure all around the world.

In the current situation, when all measures are aimed at reducing the number of human contacts, the idea of a sharp decrease of density, moving of residents out of megalopolises to individual houses outside the city, becomes quite popular again. However, according to Richard Sennett, this situation creates a paradox: denser cities are more energy efficient and such city depopulation trend may provoke a conflict between the competing demands of public health and the climate (Shenker, 2020). Cities of the post-pandemic era will compete for people, presenting their plans and strategies for preventing and combating future disasters, which should at the same time maintain a comfortable standard of living in the city. This will lead to an increase in the soft power (Nye, 2005, p. 32) of cities that will cope with this task. Not only the economic performances of the city will become important, but also the feeling of security and satisfaction with life, perhaps even the level of happiness.

However, by using a green approach to urban planning and development, combined with the ideas of new urbanism and smart city, the theory of Urbanism v.3.0. can be developed as a complex strategy of city evolution and progress based on three pillars: culture, green technologies and smart technologies. 


\subsection{Culture in post-pandemic city}

An urban agglomeration is primarily a regional cultural center. The problem of access to culture, including education, has become one of the most important during lockdown, aside from health care. Part of the problem was solved by numerous online events of cultural institutions around the world. However, that live one-on-one interaction with culture is a very special experience, which the online format cannot fully replace. This leads to the need to develop at the city public administration level new formats of cultural experience and interaction with culture in conditions of physical distancing (the term of social distancing is philologically wrong inasmuch the main idea is about physical distance between individuals and not about social stratification - a completely different connotation). Culture is one of the important tools for consolidating the soft power of cities (Nye, 2011, p. 84). Consolidating the city's soft power through digital cultural activities allows professionals from a wide variety of fields to be attracted to enrich the city's multicultural landscape, even during lockdown. The Louvre museum managed to attract 400,000 people a day through the site and accounts on social networks, which is 10 times higher than the usual traffic to the museum's social networks and official web-site. The museum used different social media based on geographic and demographic indicators: for example, using Weibo and WeChat to attract Chinese youth, and partnering with French YouTubers and influencers to attract local youth (Le Parisien, 7 April 2020). The result of such a competent SMM policy was the attraction of 10.5 million virtual visitors only in the period from March 12 to May 21 (Noce, 2020). These figures exceeded the number of real visitors to the museum in 2019 - 9.6 million (Louvre Museum, 3 January 2020). To maintain such a city soft power consolidation, it will be necessary to revise the cultural policies to ensure access to culture for all categories of citizens. Since large cultural institutions will be difficult to access for residents of outlying regions, it is necessary to develop a policy at the state level to increase the mobility of cultural values in order to be able to bring various masterpieces and performances from larger institutions to regional ones. Such an approach will not only help to consolidate the soft power of cities by increasing the diversity of cultural life at the local level, but also create additional jobs in the cultural sector of the economy. However, cultural institutions will have ethical and social difficulties because of anti-pandemic measures, since access to culture may again become the destiny of selected social groups: online - for the poor ones, offline - for the rich ones.

City museums in majority of cases can't afford an open air exhibition because of fragility of the art pieces, but it is possible in case of concert and theatrical activities, and only on condition of a good weather and capacity of stage to provide the physical distance among musicians / performers. So, relatively new format of cultural interaction can be open air concerts and theatrical performances in conditions of physical distancing. At the moment, such performances cannot be held in most theaters and concert venues due to the inevitable crowding: it will be possible to maintain the dis- 
tance between people only by frequently removing the seats in auditorium, so shows will provoke huge financial losses, unaffordable during an economic crisis. An example of this kind of preserving and consolidating city soft power during pandemics is the Hungarian Theatre of Cluj, staging some open-air shows (Hungarian Theatre of Cluj, 16 June 2020), continuing the rich cultural history of the city and creating a unique immersive cultural experience for the audience.

Regarding education, it turned out to be easier to make it available during the pandemic lockdown. An effective model for the introduction of tele-education was shown by the Babeș-Bolyai University, Romania. The institution not only effectively introduced and applied online education tools such as digital conferences (Babeș-Bolyai University, 10 March 2020), but also enlarged digital document circulation during final and admission exams (Babeș-Bolyai University, 15 May 2020).

Culture is one of the tools of soft power consolidation that will allow local public administration to manage and develop a city more effectively, raising a generation with a trans-local consciousness (Sassen, 2005, p. 38). At the same time, the phenomenon of sectionalism at the city level may arise, but in the context of continuing regionalization, this phenomenon is more likely to be another catalyst for development and growth than a source of regional separatism.

\subsection{Smart and green city}

Urbanism v.3.0. is impossible without the use of smart and at the same time green technologies. The pandemic has shown that people are ready to help each other when faced with common difficulties. Digital platforms can be a tool that brings together local communities to jointly solve problems at the community level. One of the solutions for cities during such crisis situations as the pandemic can be the development of community platforms for certain apartment buildings or areas. Now this function is often performed by chats in messengers or groups on social networks. However, specialized platforms may have more functionality for creating a local sharing economy, exchanging things, making decisions on servicing housing and surrounding territories, meeting and uniting according to interests. During a lockdown this approach will also ease the psychological tension as it will help people to feel connected and involved in creating the common good.

Because of lockdown, it is necessary to take care of the autonomy and self-sufficiency of districts and buildings. In fact, it means a returning to Plato's idea of the ideal city: Urbanism v.3.0. will provide energy efficiency, environmental friendliness, the ability to process waste, and, ideally, produce food. During the lockdown period, many were faced with problems of access to urban recreational areas such as parks and sports grounds. Most buildings in cities, outside the historical centers, usually have a flat roof, which allows to equip on it recreational areas for the community living in relative building (Belcakova et al., 2019, pp. 7-8). A small rooftop park can also become a food source for the inhabitants of the building, by transforming it into a small eco-farm (Nebuloni et al., 2019, pp. 319-324). At the same time, such zones 
will reduce the energy consumption of buildings in summer and winter for heating or cooling (Barreca, 2016, p. 725).

\subsection{Smart City and digital totalitarianism}

According to the Digital Readiness Index 2019 (Cisco, 2020), Romania had a good digitalization level in 2019, and strategies for the implementation of a smart city concept have already existed in many cities of the country. The first smart street has already been opened in Cluj-Napoca (Cluj-Napoca City Hall, 17 July 2020), more and more products and services are tied to users' smartphones. But there appear major concerns about democracy and respect of the rights and freedoms in digitalized state and city.

During the pandemic, many governments and officials used smart technology to track the pandemic, the contacts of infected individuals, and track the individuals who were quarantined. The strengthening of state control means the weakening of democracy, and emergency situations can become a catalyst for this process.

In the Roman Republic, the title 'dictator' was assigned during emergencies, most often in the military, to an elected interim ruler. The dictator received the powers of the Senate, and this made it possible to act faster. After his triumphant military victories Julius Caesar was named a lifelong dictator, after his assassination, Caesar's nephew Octavian Augustus established himself as the first Roman emperor, and the word 'dictator' acquired its modern meaning (Smith, 1867, pp. 424-430). It will be necessary to develop measures and boundaries in the legal and ethical field for operators of data, including public administration at any level, to ensure the safe use of users' information and only within the legal competence. In particular, the right for privacy must be strictly respected.

However, the very concept of private life during a pandemic or epidemic should be detailed, since the exercise of personal freedoms and rights cannot explicitly endanger the health of others members of the community. This is a kind of ethical conflict that has yet to be studied in detail. An example of such an ethical conflict can be the so-called 'COVID parties': voluntary gatherings of people with the aim of contracting the COVID-19 virus (Pietsch, 2020). It's important to note that 'bug-chasing parties' in the 1980-1990s led to a faster spread of HIV (Moskowitz et al., 2007, pp. 347-357). The ideological basis of such behavior is a distrust of the authorities and the health care system, as well as conspiracy theories that the virus does not actually exist. In this case, big data on the mass gatherings, obtained by the public administration, using various methods of analysis, including an artificial intelligence, should help prevent such events, despite their voluntary nature since we are talking about endangering not personal, but public health, which in turn will endanger the entire community and the whole city. Technological development through the digitalization of city administration and public spaces will only accelerate under the influence of pandemics, as it has happened in the past. 


\section{Conclusions}

Pandemics and epidemics have always served as a catalyst for urban development. Local public administration needs to develop a comprehensive and flexible concept for the development of urban space, taking into account all the challenges caused by the COVID-19 pandemic. The proposed concept of Urbanism v.3.0. is quite suitable for such purpose, allowing to develop a complex vision of a city evolution and progress based on three pillars: culture, green technologies and smart technologies.

This approach will allow urban spaces to be shaped or refurbished in accordance with the new requirements of physical distancing to protect public health, while maintaining the comfort of urban life and taking care of the environment. Urbanism v.3.0. will also allow to consolidate the soft power of the city by virtue of cultural institutions and smart technologies in order to attract the best specialists to it, as well as create a positive and attractive image of the city, safe and inviting for quality life from all points of view.

\section{References:}

1. Babeș-Bolyai University, 'Resolution no. 6087/15 May 2020 regarding the Cancellation of Face-to-Face Teaching Activities', 15 May 2020, [Online] available at https://www.ubbcluj. ro/ro/infoubb/covid19/deciziiubb/Admin_Council_Resolution_on_face-to-face_teaching_ activities_15.05.2020.pdf, accessed on July 23, 2020.

2. Babeș-Bolyai University, 'Resolution regarding the Cancellation of Face-to-Face Teaching Activities', 10 March 2020, [Online] available at https://www.ubbcluj.ro/ro/infoubb/ covid19/deciziiubb/ENG_Admin_Council_Resolution_on_cancellation_of_didactic_activities_10.03.2020.pdf, accessed on July 23, 2020.

3. Bacon, F. (translated by Vickers, B.), Francis Bacon, The Major Works, New York: Oxford University Press, 2008.

4. Baker, J., Cira, D. and Lall, S., 'COVID-19 and the Urban Poor, Addressing Those in Slums', World Bank Group, 1 May 2020, [Online] available at http://pubdocs.worldbank.org/ en/304801589388481883/Addressing-COVID-19-and-the-Urban-Poor-SHORT-versionrev3-logos.pdf, accessed on July 22, 2020.

5. Barreca, F., 'Rooftop Gardening. A Solution for Energy Saving and Landscape Enhancement in Mediterranean Urban Areas', 2016, Procedia - Social and Behavioral Sciences, vol. 223, pp. 720-725.

6. Bauer, C., Modern Housing, Minneapolis: University of Minnesota Press, 2020 [Digital edition].

7. BBC, 'Coronavirus: Principality Stadium to be Used as 2000-Bed Hospital', 27 March 2020, [Online] available at https://www.bbc.com/sport/rugby-union/52024970, accessed on July $15,2020$.

8. BBC, 'Eurovision Venue Turned into Covid-19 Hospital', 17 April 2020, [Online] available at https:/www.bbc.com/news/av/world-europe-52325536/eurovision-venue-turned-intocovid-19-hospital, accessed on July 15, 2020.

9. Belcakova, I., Swiader, M. and Bartyna-Zielinska, M., 'The Green Infrastructure in Cities as a Tool for Climate Change Adaptation and Mitigation: Slovakian and Polish Experiences', 2019, Atmosphere, vol. 10, no. 522. 
10. Bhugra, D., Ventriglio, A., Castaldelli-Maia, J. and McCay, L., Urban Mental Health, New York: Oxford University Press, 2019.

11. Bocaccio, G. (translated by McWilliam, G.H.), The Decameron, London: Penguin Books, 2003.

12. Brody, H., Cholera, Chloroform, and the Science of Medicine: A Life of John Snow, New York: Oxford University Press, 2003.

13. Camera Deputaților [Chamber of Deputies of Romania], 'Proiect de Lege nr. 133/2020 pentru plafonarea prețului medicamentelor și a alimentelor de strictă necesitate’ [Draft Law no. 133/2020 for Restricting the Price of Medicines and Food of Strict Necessity], [Online] available at http://www.cdep.ro/pls/proiecte/upl_pck2015.proiect?idp=18463, accessed on June 29, 2020.

14. Campanella, T. (translated by Donno, D.J.), The City of the Sun: A Poetical Dialogue, Los Angeles: University of California Press, 1981.

15. Cantor, N.F., In the Wake of the Plague: The Black Death and the World It Made, New York: Simon and Schuster, 2001.

16. Caves, R.W., Encyclopedia of the City, London: Routledge, 2004.

17. Cheng, V.C.C., Lau, S.K.P., Woo, P.C.Y. and Yuen, K.Y., 'Severe Acute Respiratory Syndrome Coronavirus as an Agent of Emerging and Reemerging Infection', 2007, Clinical Microbiology Reviews, vol. 20, no. 4, pp. 660-694.

18. Cisco, 'Digital Readiness Index 2019', 2020, [Online] available at https://www.cisco.com/ c/m/en_us/about/corporate-social-responsibility/research-resources/digital-readiness-in dex.html\#/country/ROU, accessed on July 17, 2020.

19. Cluj-Napoca City Hall, Official website, 'Molnar Piuariu - prima stradă smart din România - a fost finalizată' [Molnar Piuariu - The First Smart Street in Romania - Has Been Completed], 17 July 2020, [Online] available at https://primariaclujnapoca.ro/informatii-publi ce/comunicate/molnar-piuariu-prima-strada-smart-din-romania-a-fost-finalizata/, accessed on July 17, 2020.

20. Cokelaere, H., 'London Plans Car-Free Zones to Boost Bikes, Pedestrians', Politico, 15 May 2020, [Online] available at https://www.politico.eu/article/london-plans-car-free-zonesto-boost-bikes-pedestrians/, accessed on July 18, 2020.

21. Cooper, C. and Block, R., Disaster. Hurricane Katrina and the Failure of Homeland Security, New York: Times Books, 2006.

22. De Almeida Rodrigues, A.S.M., 'Un destin interrompu: Aliénor de Portugal, brève reine d'Aragón' [An Interrupted Destiny: Eleanor of Portugal, Queen of Aragon], in KlapischZuber, C. (ed.), Les femmes dans l'espace nord-méditerranéen. Etudes Roussillonnaises [Women in the Northern Mediterranean Space. Roussillon Studies], Revue d'Historie et d'archéologie Méditerranéennes, XXV, Canet-en-Rousillon: Éditions Trabucaire, 2013, pp. 89-96.

23. De Moncan, P., Le Paris d'Haussmann [Haussmann's Paris], Paris: Les Éditions du Mécène, 2002.

24. Dobraszczyk, P., London's Sewers, London: Shire Publications, 2014.

25. Elldér, E., 'Does Telework Weaken Urban Structure - Travel Relationships?', 2017, Journal of Transport and Land Use, vol. 10, no. 1, pp. 187-210.

26. Gagneux, R., Prouvost, D. and Gaffard, E., Sur les traces des enceintes de Paris: Promenades au long des murs disparus [In the Footsteps of the Enclosures of Paris: Walks along the Missing Walls], Paris: Parigramme, 2004. 
27. Gandy, M., 'The Paris Sewers and the Rationalization of Urban Space', 1999, Transactions of the Institute of British Geographers, vol. 24, no. 1, pp. 23-44.

28. Goodman, D.C., The European Cities and Technology Reader: Industrial to Post-industrial City, London: Routledge, 1999.

29. Gottfried, R.S., The Black Death: Natural and Human Disaster in Medieval Europe, New York: The Free Press, 1983.

30. Hansen, M.S. and Spicer, J.A., Masterpieces of Italian Painting, The Trustees of the Walters Art Gallery, London: Giles, 2005.

31. Herlihy, D., The Black Death and the Transformation of the West, New York: Harvard University Press, 1997.

32. Hungarian Theatre of Cluj, Official website, 'The Hungarian Theatre of Cluj Returns with Open-Air Performances on the Someş River Bank', 16 June 2020, [Online] available at https://www.huntheater.ro/en/news/1409/the-hungarian-theatre-of-cluj-returns-withopen-air-performances-on-the-somes-river-bank/, accessed on June 16, 2020.

33. Ifrim, M. (ed.), Medicina românească în evoluţie, viziune enciclopedică [Evolving Romanian Medicine, Encyclopedic Vision], vol. I, $3^{\text {rd }}$ edition, Bucharest: 'Vasile Goldiș' University Press, 2018.

34. Jayaweera, M., Perera, H., Gunawardana, B. and Manatunge, J., 'Transmission of COVID-19 Virus by Droplets and Aerosols: A Critical Review on the Unresolved Dichotomy', 2020, Environmental Research, 188: 109819.

35. Jordan, D.P., 'Haussmann and Haussmannisation: The Legacy for Paris', 2004, French Historical Studies, vol. 27, no. 1, pp. 87-113.

36. Kazanjian, P. and Novy, F., 'The 1901 San Francisco Plague Commission Investigation', 2012, Clinical Infectious Diseases, vol. 55, no. 10, pp. 1373-1378.

37. Kirkland, S., Paris Reborn: Napoléon III, Baron Haussmann, and the Quest to Build a Modern City, London: Picador, 2014.

38. La Republica, 'Covid 19, Emergency: a Bergamo nel focolaio di massimo contagio sorge il nuovo ospedale in Fiera' [Covid 19, Emergency: in Bergamo, in the Outbreak of Maximum Contagion, the New Hospital Stands in the Fiera], 30 March 2020, [Online] available at https://www.repubblica.it/solidarieta/emergenza/2020/03/30/news/emergency_a_berga mo_per_il_nuovo_ospedale_in_fiera-252718484/, accessed on July 15, 2020.

39. Le Parisien, 'Pendant le confinement, le Louvre explose les records de fréquentation sur Internet' [During the Confinement, the Louvre Exploded Internet Attendance Records], 7 April 2020, [Online] available at https://www.leparisien.fr/paris-75/pendant-le-confine ment-le-louvre-explose-les-records-de-frequentation-sur-internet-07-04-2020-8295876. php, accessed on June 25, 2020.

40. Losavio, C., 'I prodotti agricoli "a chilometri zero" nelle leggi regionali' [Agricultural Products “at Zero Kilometers” in Regional Laws], 2011, Agricultura Istituzioni Mercati, no. 3, pp. 93-107.

41. Louvre Museum, Official website, '9.6 million Visitors to the Louvre in 2019', 3 January 2020, [Online] available at https://presse.louvre.fr/9-6-million-visitors-to-thebr-louvrein-2019/, accessed on May 25, 2020.

42. Mackowiakm, P.A. and Sehdev, P.S., 'The Origin of Quarantine', 2002, Clinical Infectious Diseases, vol. 35, no. 9, pp. 1071-1072. 
43. Mamelund, S., 'Profiling a Pandemic. Who Were the Victims of the Spanish Flu?', 2017, Natural History, pp. 6-10.

44. Maneglier, H., Paris Impérial, Paris: Armand Colin, 1990.

45. McCarty, M., 'Introduction to Public Housing', Washington: Congressional Research Service, [Online] available at https://fas.org/sgp/crs/misc/R41654.pdf, accessed on July 20, 2020.

46. Meerovich, М., 'Советский опыт 1920-1930-х' [Soviet experience of the 1920s-1930s'], in Belov, A. (ed.), Массовое домостроение в СССР в 1950-1980-е: история в постановлениях [Mass Housing Construction in the USSR in the 1950-1980s: History in Decrees], Moscow: ËLKA Press, 2016, pp. 26-41.

47. Milza, P., Napoleon III, Paris: Perrin, 2004.

48. Ministry of Housing, Urban and Rural Affairs of Denmark, 'Fact Sheet on the Danish Social Housing Sector', [Online] available at http://www.mbbl.dk/sites/mbbl.dk/files/do kumenter/publikationer/fact_sheet_on_the_danish_social_housing_sector.oct2014.pdf, accessed on June 2, 2020.

49. Mordechai, L., Eisenberg, M., Newfield, T.P., Izdebski, A., Kay, J.E. and Poinar, H., 'The Justinianic Plague: An Inconsequential Pandemic?', 2019, Proceedings of the National Academy of Sciences, vol. 116, no. 51, pp. 25546-25554.

50. More, T. (translated by Baker-Smith, D.), Utopia, London: Penguin Books, 2012.

51. Moskowitz, D. and Roloff, M., 'The Existence of a Bug Chasing Subculture', 2007, Culture, Health \& Sexuality, vol. 9, no. 4, pp. 347-357.

52. Nebuloni, A., Buratti, G. and Meraviglia, M., 'Zero Kilometre Plants Production. An Integrated Design Application', in Ambrosio, M. and Vezzoli, C. (ed.), Designing Sustainability for All, Milan: Edizioni POLI.design, 2019, pp. 319-324.

53. Noce, V., 'French Museums Reveal Plans to Re-Open in June and July', The Art Newspaper, 29 May 2020, [Online] available at https://www.theartnewspaper.com/news/french-muse ums-open, accessed on June 25, 2020.

54. Nye, J.S. Jr., Soft Power: The Means to Success in World Politics, New York: Public Affairs, 2005.

55. Nye, J.S. Jr., The Future of Power, New York: Public Affairs, 2011.

56. Ogen, Y., 'Assessing Nitrogen Dioxide (NO2) Levels as a Contributing Factor to the Coronavirus (COVID-19) Fatality', 2020, Science of the Total Environment, 726:138605.

57. Oxford University, Oxford Dictionary of Art and Artists, $4^{\text {th }}$ edition, New York: Oxford University Press, 2009, pp. 64-66.

58. Papayanis, N., Planning Paris before Haussmann, Baltimore: Johns Hopkins University Press, 2004.

59. Perlman, F., Against His-Story, Against Leviathan, Detroit: Black \& Red, 1983.

60. Pietsch, B., 'Texas Hospital Says Man, 30, Died after Attending a 'COVID Party', The New York Times, 12 July 2020, [Online] available at https://www.nytimes.com/2020/07/12/ us/30-year-old-covid-party-death.html, accessed on June 25, 2020.

61. Plato (translated by Cornford, F.M.), The Republic of Plato, New York: Oxford University Press, 1970.

62. Reid, C., 'New Zealand First Country to Fund Pop-Up Bike Lanes, Widened Sidewalks during Lockdown', Forbes, 13 April 2020, [Online] available at https://www.forbes.com/ 
sites/carltonreid/2020/04/13/new-zealand-first-country-to-fund-pop-up-bike-lanes-wid ened-sidewalks-during-lockdown/, accessed on July 15, 2020.

63. Rusu, G.V., 'Clujul și „Moartea Neagră”. Despre epidemiile de ciumă ce au afectat orașul în secolele XVI-XVII' [Cluj and „Black Death”. About the Plague Epidemics that Affected the City in the XVI-XVII Centuries], in Dâncu, V.G. (ed.), Povești despre Cluj [Tales about Cluj], vol. IV, Cluj-Napoca: Editura Școala Ardeleană, 2018, pp. 67-82.

64. Sassen, S., 'The Global City: Introducing a Concept', 2005, The Brown fournal of World Affairs, vol. XI, no. 2, pp. 27-43.

65. Shenker, J., 'Cities after Coronavirus: How Covid-19 Could Radically Alter Urban Life', The Guardian, 26 March 2020, [Online] available at https://www.theguardian.com/world/2020/ mar/26/life-after-coronavirus-pandemic-change-world, accessed on July 16, 2020.

66. Sicker, M., The Struggle over the Euphrates Frontier, The Pre-Islamic Middle East, Santa Barbara: Greenwood, 2000.

67. Smith, W., Dictionary of Greek and Roman Biography and Mythology, vol. I, Boston: Little, Brown and Company, 1867, [Online] available at https:/quod.lib.umich.edu/m/ moa/acl3129.0001.001?view=toc, accessed on July 22, 2020.

68. Spring, M., 'Coronavirus: The Human Cost of Virus Misinformation', BBC, 27 May 2020, [Online] available at https://www.bbc.com/news/stories-52731624, accessed on July 15, 2020.

69. Ziegler, P., The Black Death, London: Penguin Books, 1998. 